visueelgestremdes word dus nie gebied nie. Baie van die sake wat te berde gebring is, is egter vir alle sodanige dienste ter sake.

Hoewel hierdie soort inligtingmedia en -dienste die afgelope dekades in veral ontwikkelde lande verder verbeter is, is min werklike vordering buite die sfeer van inligtingtegnologie gemaak. Enersyds bly gesigsgestremdes afhanklik van spesiale inligtingmedia wat soms deur spesiale biblioteekdienste aan hulle gelewer word. Andersyds is hulle ook aangewese op die inligtingmedia en -dienste wat aan siendes verskaf word.

Die voordragte is sterk praktykgerig. Net in enkele gevalle word bibliografiese verwysings verskaf. Die voordragte kan met vrug bestudeer word deur almal wat met die produksie en verspreiding van inligting aan gesigsgestremdes te make het. In die geval van grootdruk is dit in die Suid-Afrikaanse konteks belangrik om te besef dat hierdie medium ook met goeie gevolge deur nuutgeletterdes en by die aanleer van 'n vreemde taal benut kan word.

\title{
J. BEKKER
}

\section{Looking ahead: a practical look at new developments in library and information services for visually impaired persons}

\author{
Hogg, Frank N., red. \\ Anstey: Ulverscroft Large Print Books Ltd. \\ 1994
}

ISBN 0-7089-3494-3

Hardeband, 199p.

$£ 25$

Frederick Thorpe het internasionaal bekendheid verwerf vanweë die talle Engelse boeke in grootdruk wat sy maatskappy in die Ulverscroft-reeks gepubliseer het. In 1990 is 'n internasionale konferensie ter ere van hom aan die University of Wales te Aberystwyth gehou. Die verrigtinge is gepubliseer onder die titel, 25 years of library services to visually impaired persons (Anstey: Ulverscroft, 1991, 146p.), met Frank Hogg as redakteur.

Hierdie byeenkoms het bekend geword as die VIP (Visually Impaired Persons) First International Conference. Die boek wat hier geresenseer word, dek die tweede sodanige konferensie wat in 1994 aan die University of Nottingham gehou is. Laasgenoemde is deur meer afgevaardigdes as die eerste een bygewoon en die verrigtinge beslaan ook meer bladsye. 'n Derde konferensie word in die vooruitsig gestel.

Van die 240 afgevaardigdes by die tweede konferensie het net twee uit Afrika gekom: een uit Suid-Afrika en die ander een uit Zimbabwe. Die Skandinawiese lande was goed verteenwoordig. Die 17 voordragte is hoofsaaklik deur Britte gelewer. 'n Internasionale beeld van biblioteekdienste aan
Emeritusprofessor, Departement Inligtingkunde, Universiteit van Suid-Afrika, Pretoria. 